Scottish

\title{
The shifting of the climatic belts
}

\section{Prof. Geh. Reg.-Rat. Albrecht Penck}

To cite this article: Prof. Geh. Reg.-Rat. Albrecht Penck (1914) The shifting of the climatic belts, Scottish Geographical Magazine, 30:6, 281-293, DOI: 10.1080/14702541408541553

To link to this article: http://dx.doi.org/10.1080/14702541408541553

\section{册 Published online: 30 Jan 2008.}

Submit your article to this journal

\section{Article views: 6}

Q View related articles $₫$

4 Citing articles: 5 View citing articles 


\title{
THE SCOTTISH
}

\section{GEOGR A P H I C A L}

\author{
MA G A Z I N E.
}

\section{THE SHIFTING OF THE CLIMATIC BELTS. ${ }^{1}$}

By Prof. Geh. Reg.-Rat. Albrecht Penck, of Berlin University, Gold Medallist of the R.S.G.S.

\section{(With a Sketch-Map.)}

Climate does not remain constant. It fluctuates continuously, and that between varying limits. Brückner has shown that on the Continents, in regular variations, dry and warm, moist and cool years alternate with one another. The fluctuations of our glaciers are witnesses to the longer periods of dry and wet years. They advanced in the Alps during the eighteenth century, and attained their maximum there in the first half of the nineteenth century. Thereupon there followed a period of retreat, and the same holds true for the majority of the glaciers upon our earth. There are, moreover, many indications that, some centuries after the beginning of the Christian era, there was in Central Asia a period of extreme dryness, which exercised a considerable influence on the conditions of settlement, and even, it would appear, upon migration. Still greater have been the variations of clim in the geological past. Nothing indeed has roused greater attentiou among explorers and others than the great Ice Age, during which the north of Europe and the northeast of North America were covered by immense masses of inland ice, and all the higher mountains and mountain ranges of the world were more extensively glaciated than is the case to-day.

At present the question of the cause of the Ice Age is arousing renewed and keen discussion, and, as from the beginning has been the case, two theories are still advanced in opposition to one another; according to the one, the Ice Age was a universal condition affecting the

1 An Address delivered before the Society in Edinburgh on March 19, 1914. Translated into English by Miss Grace Meiklejohn.

VOL. $\mathrm{XXX}$. 
entire earth; the other accounts for the former remarkable size of the glaciers solely by means of local causes. Frankly, we can easily imagine glaciers advancing without a universal variation of climate. If we consider, for example, the Scottish Highlands raised by 5000 feet, they would, of course, be covered by glaciers, which we may suppose would extend to the sea, and end in a climate corresponding to that which Scotland at present enjoys. The presence of glaciers, indeed, does not permit of the conclusion that the whole surrounding country has a specially cold climate. Many glaciers at the present day descend into regions of luxuriant vegetation; for example, those of New Zealand, Patagonia, and many others on the west coast of North America-in British Columbia and Alaska. Therefore, when we find anywhere traces of earlier and more extensive glaciation we can by no means conclude that there glacial conditions must have prevailed. But although the tongues of large glaciers, which descend from high mountain ranges, may extend far into a zone of mild climate, it is still evident that they all take their birth under distinct climatic conditions, easily recognised by the fact that the mass of the snow precipitated does not melt where it falls, but accumulates and is drained away by glaciers. We call this climate zone the Snow Climate. In nature it is often marked off sharply from its surroundings; sometimes, however, there is no hard and fast dividing line. But, whether clearly marked or indefinite, this is the snow-line. All glaciers, unless they debouch in the sea, extend beyond the snow-climate region, descending below the snow-line, to melt usually in a humid climate. In the snow climate they are autochthonous, but in the humid they are allochthonous, and where they melt they leave behind considerable moraine deposits. Where such are found, there do not prevail, as a rule, the climatic conditions under which glaciers are formed, but rather climatic factors by which glaciers are destroyed.

In order to understand the essence of the Ice Age we must go where the old glaciers had their birth, we must seek out their roots. Here an important fact lends us guidance. Glaciers formed in the folds of the mountain slopes oat into the latter and grind out a characteristic cuplike form - the Corrie. In its details this corrie formation still requires considerable study. It is certain that the chasm which separates the glacier from the surrounding rock, called by English writers the Bergschrund, plays an important part in its formation. All debris from the encircling wall falls into this chasm, and gets under the ice, which, with its aid, grinds farther into the ground. Where corries are found, glaciers have once lodged, and a snow climate has at one time obtained. The corries of Scotland afford us indubitable proof that the entire Scottish Highlands once rose above the snow-line, which on the coast 'of Skye was about 1000 feet above sea-level. As regards the Lake District, we learn from the corries of Cumberland that the snow-line was 1300 1500 feet, and in Wales the coombs prove that similar conditions existed. All the mountain ranges of Great Britain rose during the Ice Age above the snow-line, while at the present day the highest peaks of Scotland lie below it.

We find much the same thing when we turn to Germany. None of 
the German mountains, with the exception of the Alps, rise above the snow-line. But all the higher mountains possess corries, some--as in the Black Forest and the Vosges-occupied by dark lakes, as are also those of the Bohemian Forest; the "Schneegruben" of the "Riesengebirge" are also corries, from which at one time small glaciers descended, while still farther east the so-called "eyes of the sea" found in the High Tatra are tarns lying in deep and magnificent corries. During the Ice Age the snow climate began at a height of between 2500-4000 feet above sealevel, and the snow-line lay lower in the Vosges and Black Forest in the west than in the Riesengebirge or Tatra in the east, being highest in the last, higher than in the Riesengebirge. The snow-line was also very low along the north edge of the Alps. Here the higher chains are studded with corries. The Karwendel gets its name from the sheer walls of rock ( $W_{\text {iande) }}$, which tower above its numerous corries (Kaie). Similar phenomena are found in the Kaisergebirge and in the ranges of the Central Alps. Here in the Alps we get the first clue to the depression of the snow-line during the Ice Age, for here the highest peaks still rise above that line, which is clearly defined, while that of the Ice Age lay some 4000-4300 feet lower.

What holds good for Central Europe holds good also for North and South Europe. "The "Butner" of Norway are simply corries, and when we find them in the Lofoten Islands at sea-level we are led to conclude that within the Arctic Circle the snow climate began at sea-level. It is a remarkable fact that the snow-line lay low also in the Mediterranean region. In the Sierra de Estrella and in north-west Spain, for instance, it is found at about 4700 feet, while in the interior of Spain, in the Sierra de Gredos and Sierra de Guadarrama only at 6000-6600 feet, as the corries indicate. It is plain, then, that the snow-line rose from the coast towards the centre of Spain. The same phenomenon as regards the limits of perpetual ice and snow appears in the Balkan Peninsula. The snow-line lies extraordinarily low on the east coast of the Adriatic. The mountains surrounding the Gulf of Cattaro carried glaciers which descended to 3700 feet above sea-level and left there huge morainic deposits. We may conclude that there the snow-line of the Ice Age was found at about 4700 feet, while in the heavily corried Rila Mountains south of Sofia we have to ascend 2000 feet higher before we reach it. Further, in the Pyrenees we find the snow climate of the Ice Age beginning in the west at 4600 feet, in the east at 6600 feet. The present-day conditions correspond to these of that remote age, only the snow-line is now found at least 3300 feet higher than was then the case. The same thing meets us in the Caucasus. The snow-line lay on the Black Sea side at 4600 feet, that is, it lay, just as in the Alps, 4300 feet below the present line. And, just as we find to-day, the snow-line rose in the Middle Caucasus, reaching its maximum in the mountains overlooking the Caspian Lake. In the Mediterranean region it was found during the Ice Age 3300-4000 feet lower than at present, and rose in every peninsula from the west coast towards the interior. This all goes to prove that then, as now, the west winds were the great rain and snow-bearing winds. 
Not only, however, in lands near the sea, but in the hearts of the great continents also, the snow-line lay, during the great Ice Age, lower than at present. We find this the case in Asia. The Altai mountains in the north, and farther south the Tianshan, carried at one time glaciers much larger than the present ones, and mountains which are now practically without snowfields had formerly by no means inconsiderable glaciers. The Steppe mountains of the Kara-Teke-Takh, south of Tianshan, as Gröber has pointed out, are well supplied with corries. According to these observations, we are obliged to fix the earlier snow-line in this region at about 6600 or 8000 feet. The present-day line, on the other hand, is certainly not below 11,500 feet, and indeed, in the neighbouring range of the Tianshan, it is as high as 13,500 feet. It follows, therefore, that the snow-line in Asia was from 3300-4600 feet lower then than it now is-in short, that its average retreat (4000 feet) is exactly the same as it has been proved to be in Europe.

For long it has been an open question whether, along the Pacific coasts of the Old World, the region of perpetual ice and snow was formerly more extensive than is the case to-day. Within recent years, however, light has been thrown upon the problem. In Kamchatka extensive records of the Ice Age have been found. Corries abound, too, in the Japanese Alps, the narrow ridges of which mountains bear a striking resemblance to those of the Eastern Alps. These corries, found 8000-9000 feet above sea-level, oblige us to follow Oseki in fixing the snow-line of the Hida range, during the Ice Age, at about 8000 feet. To-day, its peaks, towering to over 10,000 feet above sea-level, are clear of snow, and only some 200 miles to the south-east, Fuji Yama rises 12,400 feet, and yet falls short of the region of eternal snows. So, in Japan again, we meet with a marked retreat in the snow-line - a retreat of certainly, at least 2300 feet, and more probably of 3300 feet. Thus we have evidence of an Ice Age in Japan, as clearly marked as in the same latitude in Europe, namely, in the Sierra Nevada in Spain.

Even in the tropics evidences of an Ice Age are forthcoming. Nowhere are these more evident than on Mount Kenya, situated nearly under the equator. On the slopes of this mountain are extensive corries, some occupied by tarns, as, for example, that containing the little Höhnel Lake, 14,000 feet above sea-level. Gregory was able to trace old moraines down to 10,000 feet, whilst the present-day glaciers of Kenya in spite of their sheltered situation descend only to 15,600 or at most 15,300 feet, ending some 5400 feet above the old terminations. We may therefore venture to say that the snow-line of the Ice Age was at least 4000 feet lower than the present line, and that the snow climate during that age descended at the equator then, exactly as much as it did in Europe. This important conclusion finds further justification, when we turn our attention to other mountains in equatorial regions. On Kilimanjaro as on Chimborazo traces of the Ice Age are found, although here corries are lacking. These, however, appear to occur in the high mountains of New Guinea. On the north slope of Mount Carstentz, which rises to 15,706 feet-i.e. 1500 feet above the snow-line -Wollaston found numerous traces of glaciation, extending as low as 
12,000 feet, and he himself believes that stones picked up only 8500 feet above sea-level showed signs of glacial action.

The existence of an Ice Age in the southern hemisphere has long been an established fact. On the west coast of Patagonia and of South Island, New Zealand fiords indicate that there glaciers extended to sea-level, exactly as was the case on the west coast of lands in the temperate latitudes north of the equator. But whilst in the northern hemisphere the fiords appear in Europe in latitude $52^{\circ} \mathrm{N}$. and in North America in $48^{\circ} \mathrm{N}$., in the southern hemisphere they appear in latitudes as low as $44^{\circ} \mathrm{S}$. in New Zealand, and in Patagonia even in $42^{\circ} \mathrm{S}$.$6^{\circ}$ to $10^{\circ}$ lower in latitude than in the northern hemisphere. This harmonises with the fact that glaciation in the southern hemisphere is more considerable than in the same latitudes in the northern. The present glaciers of New Zealand are much larger than those of the Pyrenees (in the same latitude). They require in $43^{\circ} \mathrm{S}$. lat. a snowline about 1600 feet lower than in $43^{\circ} \mathrm{N}$. lat. This difference in the height of the snow-line at present in the northern and southern hemispheres corresponds with a similar difference during the Ice Age. While in Japan we find corries in mountains from 9500-10,500 feet, we find them in corresponding latitudes in Australia in mountains as low as Mount Kosciusko, 7336 feet, and, in $42^{\circ} \mathrm{S}$, Tasmania was at least as well supplied with glaciers as the Vosges and Black Forest, although the latter lie in $6^{\circ}$ higher latitude. In southern New Zealand from $44^{\circ} \mathrm{S}$. lat. southwards, glaciers descended from peaks 5200-5900 feet high, and ended only when sea-level was reached, whilst in corresponding northerly latitudes during the Ice Age the glaciers at the west end of the Pyrenees, and even the very considerable ones in the hill land of Orense in Spain, never passed out of the interior of the country. It follows that the snow climate in the temperate latitudes of the southern hemisphere, as in the temperate latitudes of the northern, and as at the equator itself, descended at least 3900-4300 feet lower than is to-day the case. In other words, the retreat of the snow-line of the Ice Age is a universal retreat-it holds true for the whole world.

We cannot, in view of these facts, regard glaciation during the Ice Age as due to local conditions, but must consider it in relation to a universal alteration in climate. Two possibilities here present themselves. Granted that the snow climate demands an amount of precipitation in the form of snow so great that it cannot be melted, then an increase in the snowfall, or a decrease of temperature, will lead to an extension of the snow climate and to a lowering of the snow-line. Both views have found champions.

It has been repeatedly emphasised that the Ice Age in lands where glaciation did not take place was distinguished as a period of specially abundant rainfall-as a Pluvial Period. This supposition seems to derive considerable support from phenomena found in the Great Basin of North America. On its bottom we find to-day the Great Salt Lake. It is surrounded by far-reaching old shore-lines, which show two former levels of a larger lake, and down to these lines are abundant evidence of Ice Age glaciers, which descended from the Wahsatch Range 
to the former lake. There can be no doubt that here the greater extent of the then existing glaciers, due to the lower altitude of the firn or névé line, was co-existent with the higher level of the lake, which at that period found an outlet in the north through the Snake River. The then existing high level of the lake indicates that in former times here a moister climate obtained, and this without further investigation has been connected with a general Pluvial Period. But the conclusion is drawn without justification. Just as extension of glaciers is conditioned either by increase of precipitation, or by decrease of temperature, so the rise of the level of an inland lake depends either upon the increase of the precipitation in its drainage area, or a diminution of evaporation in the said area and on the surface of the lake itself, due again to a lowering of the temperature.

The phenomena furnished by the Great Salt Lake are up to a certain point of a local nature. Let us go south. We pass a succession of shallow basins exactly like that in which the Great Salt Lake lies. But in these more southerly basins, the bolsons of Nevada and California, we do not find the old shore-lines which would indicate that they have been once filled by lakes. Here there are no traces of a Pluvial Period, in spite of the fact that neighbouring mountain ranges, such as the Sierra Nevada of California and the San Francisco Peak, bore glaciers during the Ice Age. The development of these glaciers did not take place during a period of excessive precipitation, for during such a period those great empty bolsons would have filled with water. So here we recognise that the Great Ice Age beyond the limits of the glaciated regions was not a general Pluvial Period, but that, on the contrary, during that age desert regions similar to those of the present day did exist. The bounding lines, however, between these arid regions and the regions of abundant precipitation have altered. In the great basins they now lie much farther north. This we learn from the phenomena in the environment of the Great Salt Lake. These prove to us that during the Ice Age not only was the snow-line lower than it now is, but that another important dividing line, that, namely, which separates humid from arid regions, and which we may define as the limit of dryness, has altered. This limit of deficient precipitation, which is to-day found north of the Great Salt Lake in about $44^{\circ} \mathrm{N}$. lat., lay during the Great Ice Age at least $5^{\circ}$ farther south.

Numerous signs indicate that a similar shifting of the limit of dryness in the Old World has taken place in the south of the Mediterranean. Attention has been frequently called to the extensive wâdis in Algeria and in the north of the Sahara, which go to show that formerly the rivers of that region were more considerable than the present ones. But in treating of old river beds and valleys there is need of a certain caution. Although in the Great $\mathrm{Erg}$, in the dunes of southern Algeria, we are able to trace great river beds, it does not follow absolutely that in this region a more humid climate existed than does now. Like glaciers, rivers are certainly products of a definitely humid climate, but they not infrequently flow from such a region into a dry one, where by evaporation they partly or wholly disappear. Of this 
the Nile is a good example. In its long course from Khartum through Nubia and Egypt it is a stranger in the arid climate through which it passes. The river here is allochthonous; only farther south is it autochthonous. In Egypt, we cannot argue from the Nile that a humid climate prevails there, and just as little is it possible to conclude from the old rivers of the Great Erg that in that region the climate was in bygone ages a humid one. But there can be no doubt that humid conditions obtained once farther south in the territory of the oases on the Ahaggar mountains and on the surrounding plateaus.

Moreover, we cannot conclude from the numerous little runnels with which the slopes of the Nile valley are furrowed, that the region formerly enjoyed a much more abundant supply of water, for we know that from time to time in the most arid lands rain falls so heavily that the water-courses on the hillsides are temporarily filled and exercise a powerful erosive influence on their valleys. For years the Wâdi Hof at Heluan, not far from Cairo, was dry-so long indeed did it remain in this condition that one could easily distinguish the path worn across it by the passing and repassing of caravans of camels. From time to time, however, it is filled with water, and that to such an extent that railway traffic between Cairo and Heluan has been interrupted by the flooding of the line. Valleys are not indubitable evidence of a humid climate, as corries are of the snow climate. In arid, as in humid climates, small rivers may arise, and the transitory streams of the arid regions can carve out little valleys as successfully as the permanent rivers of humid lands. But a different fate awaits the rivers of the two regions. Big rivers never develop in arid zones, and therefore there is a want of the power of land sculpture, possessed to such an extraordinary degree by the larger rivers in the humid belts. For these rivers keep open their way to the sea, remove the obstacles in their path, cut through mountain chains, and bear along the debris brought down to them by the raging mountain torrents.

In arid zones we do not find the continuous grading of the land to sea-level. The land surface tends rather to crumble into solitary closed basins, in which the water gradually dries up, basins which may be described as more or less extensive pans. On a small scale these are found in the Transvaal and in the west of the Orange River Colony. Here we are dealing with pans hollowed out by wind action, or those hidden among sand ridges heaped up by the wind. The bolsons of the south-west States of South America, those in Mexico, and those in the North Argentine are pans. Numerous pans, temporarily occupied by lakes, are spread over the west of Australia. The pan, in short, is as characteristic a formation for the arid region as the corrie is for the snow climate. The pans also furnish us with proofs of variations in climate, for just at the point where the arid climate gives place to the humid the pans are filled with water and become lakes. That the Great Salt Lake was once filled to overflowing affords certain proof that at one time in the northern part of the Great Basin a humid climate prevailed, which in its turn has once more in our own day given place to an arid one. Again the lack of lake terraces in the bolsons of Nevada and California 
indicates that climate conditions there have always been arid. To the same conclusion points the want of shore-lines along the former lakes in the oases of the Libyan Desert in west Egypt. However numerous the wâdis may be here, the emptiness of those basins make it plain that since a long past geological period, and moreover throughout the Ice Age, the conditions here have been arid.

These empty pans of North America extend to Mexico and indeed to the vicinity of the capital itself. Here, however, we find them partly filled with water, and thus containing lakes, as is the case also when we approach the northern boundary of the region under consideration. But whilst the Great Salt Lake of the north is emphatically saline, the lakes round Mexico City are very slightly salt - almost fresh, in fact. This can only be explained by regarding the latter as much younger than the Great Salt Lake and its immediate neighbours; the feeders have not yet had time to make considerable saline deposits.

In the Old World we meet the same fact. In Africa along the northern border of the great desert belt lie the markedly saline lakes of the Shotts of Algeria and of the oases in the northern Libyan Desert. Farther south the pans are quite empty, as, for instance, the oases of Khargeh and Farafrah west of Egypt, and those of the depression Bodele south of the highland of Tibesti. West of Air, however, the flat pan of Tesellamen is occasionally flooded, and farther towards the south-east there occurs another flat pan constantly under water. The latter lies in the Lake Chad basin, and the water of this lake is only slightly saline and contains fish and mollusca the same as those found in the Shari.

This identical succession is repeated in the southern hemisphere. From the Peruvian coast through Atacama to the northern Argentine there stretches a strip of desert full of numerous, for the most part empty, pans. Those in the south are occupied by small extremely saline lakes, for example, the Salar de Tres Quebrades, from which the people of Chile obtain salt. In the north we find, however, the extensive, brackish, almost fresh lake of Aullagas occupying one of these pans and supplied from Lake Titicaca. So deficient is it in saline matter that the fish and mollusca of Lake Titicaca abound in it also. Lake Titicaca itself, however, impresses one as definitely a pan, filled to overflowing with water, and recalls the Great Salt Lake as it was during the Ice Age, when the Snake River formed its outlet. In Africa there are not lacking indications of a similar development. There are numerous empty pans found in the Kalahari, and in the north of Cape Colony many of the pans may be regarded as typical salt pans. In the north of the Kalahari, however, we come across an extensive pan with only slightly brackish water-water in which the fresh water fish of the feeders can continue their existence. I refer, of course, to the great Etosa pan, which corresponds to Lake Chad. Farther east there are without doubt saline lakes in the Ngami basin, but there also we find larger pans which are from time to time filled with fresh water. Thus from the New as from the Old World we may draw the following conclusion:--on the equatorial side of the Great Desert regions are flat pans occupied with slightly saline or occasionally fresh water, while on the polar side occur strongly saline 


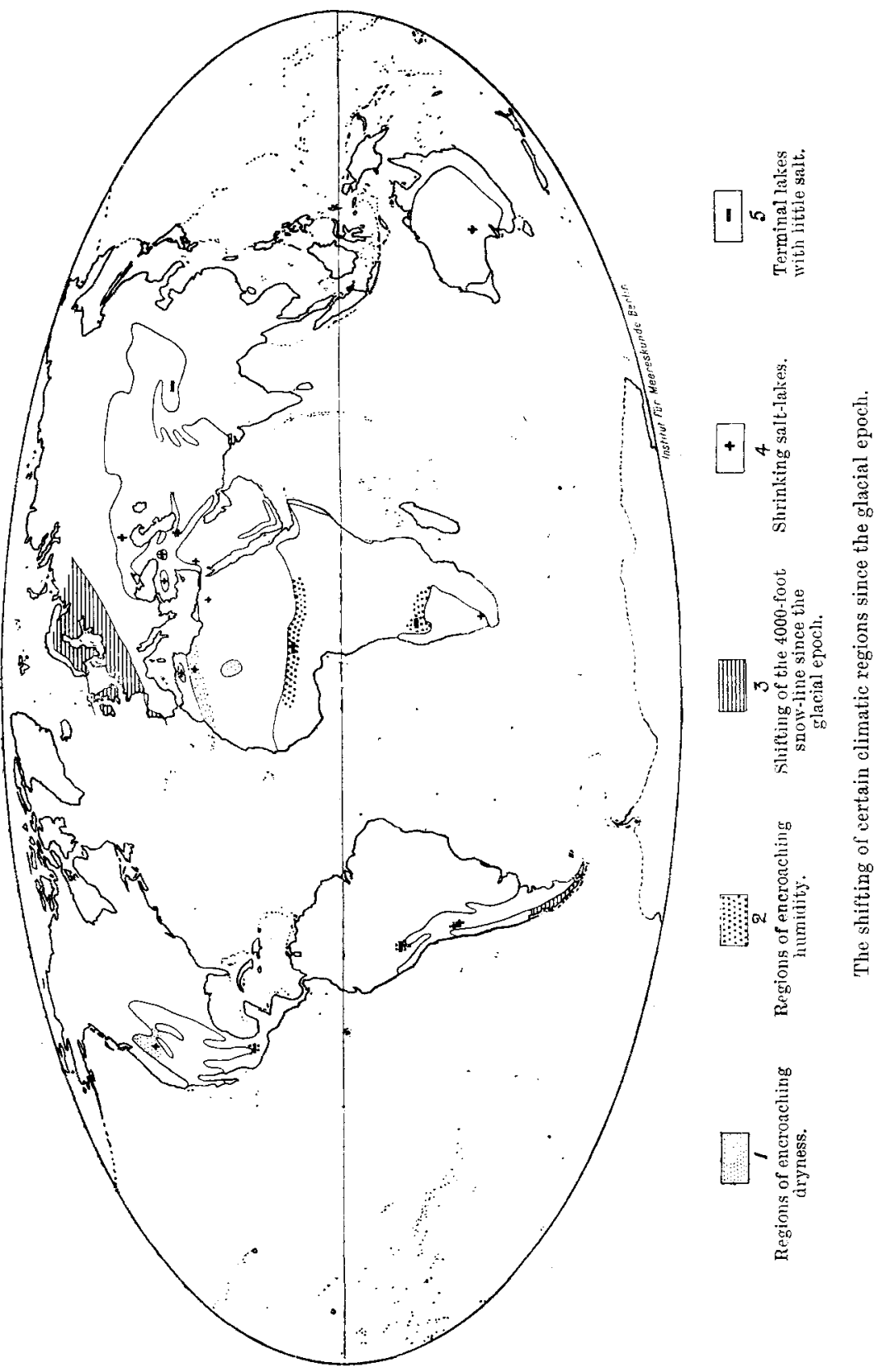


lakes (see Map). In Asia these salt lakes are represented by the Dead Sea, the lakes of Urmia and Wan, and the abundant small lakes on the steppes north of the Caspian.

In the water of these lakes the saline matter often reaches a maximum, and many of them resemble a mother ljquor, such as would occur at the close of a long period of evaporation, whilst on the other hand the terminal lakes, slightly salt or fresh, on the equatorial side of the desert belt, would rather suggest a present period of increasing precipitation. Many features on their shores support this theory. Lake Chad quite evidently floods the dune region to the north, converting the sand hills into islands, exactly as the rising Caspian in the neighbourhood of Astrakan does. Numerous bays bear witness to the fact that old valleys have been submerged by the waters of Lake Titicaca. Here again there must be a striking rise in the water level. In the Great Salt Lake of North America, on the other hand, we have evidence of shrinkage. One meets nothing of this kind round the shores of Titicaca, but round the Dead Sea there are extensive shore-lines, which indicate that the sea was formerly larger, and that the water-level stood higher. On the equatorial side then of the desert belt we have to do with rising lakes, on the polar side with shrinking pans. Both point to variations in climate, to increase of aridity on the polar side, to increase of humidity on the equatorial side. From the conditions prevailing in the Great Basin we may conclude that this has happened since the Ice Age; since that period the arid zone has shifted towards the poles. On their polar sides river systems are now differentiated into their components, the main river is wanting, only the affluents still subsist. On their equatorial boundary, however, such differentiated river systems become integrated and main rivers are formed. Here the desert dunes become covered by vegetation, whilst on the other side they invade districts covered by vegetation. Very characteristic are the phenomena in the Sahara. In the north there are living dunes consisting of bare wind-blown sand; the dead dunes, however, covered by sparse vegetation, are confined to the south, and these dead dunes streteh beyond the arid region far into the humid zone along the right bank of the Niger. The dunes of the Kalahari are for the most part dead, and, so stationary are they, that the traveller can find his bearings from the number of dunes which he passes. The circumstances which have led here to the formation of dunes no longer obtain on the equatorial side of the desert zone, but prevail solely at the present day on the polar border.

All this leads us to assume that the area of extreme aridity in Africa once lay much nearer the equator than it does to-day, exactly as was the case in both Americas, and, guided again by the phenomena of the Great Basin, we may fix this period in the Ice Age. The Great Ice Age presents itself then neither as a period of extreme cold-as was originally held-nor as a period of excessive humidity over the whole earth, but as a period during which the climate belts were shifted into lower latitudes. During this period the great arid regions of the world lay some 4-5 degrees nearer the equator, while the snow-line was found more than 3300 feet lower. A period characterised by the 
low position of the climate zones we may distinguish as a cataclimatic period.

We need hardly point out that no real difference exists between the movement of the snow-line to lower altitudes, and the movement of the limit of dryness towards lower latitudes, for the lowering of the snowline indicates merely the extension of the region of eternal snows, and the pushing of its limits nearer to the equator. The 4000 -foot snow-line which to-day runs along the west coast of Norway extended during the Ice Age as far south as the north edge of the Alps, and whilst now it leaves the continent on the Norwegian coast in $59^{\circ} \mathrm{N}$. lat., its point of departure during the Ice Age was at $42^{\circ} \mathrm{N}$. lat., in the north-west of Spain. It extended in short, as shown on our map (p. 289), $17^{\circ}$ farther south than now-roughly some 1200 miles. Eastward the shifting is still more remarkable, for the line traversed the Urals during the Ice Age in $62^{\circ}$ N. lat.--a point some 1400 miles from its present position.

Similar has been the shifting of the 4000-foot snow-line on the west coast of South America. To-day it is found in the extreme south of Patagonia. During the Ice Age it was situated about $42^{\circ} \mathrm{S}$. lat., some 900-1000 miles nearer the equator. But the shifting of the higher snowlines becomes less. The 6000 -foot snow-line which we find to-day in Central Europe was shifted during the Ice Age, at most some 700 miles farther south-about to the middle of the Mediterranean area-and the 9000 -foot snow-line, instead of being situated in the southern Alps and the east end of the Pyrenees, was met with certainly not farther south than the High Atlas, that is a shifting of only some $8^{\circ}$. When we examine the 16,000-foot snow-line in South America we find a still smaller variation. It appears only to have moved from the latitude of Aconcagua to not quite so far as that of Sierra de Famatina, that is only some $2 \frac{1}{2}^{\circ}$ nearer the equator.

In consequence of this insignificant shifting of the higher snow-lines towards the equator one peculiarity in the course of the present line holds good also for that of the Ice Age. It reaches its maximum altitude not at the equator, but north and south of it in the arid areas. It rises to more than 20,000 feet in south Tibet, and in that part of the Andes of South America found between $18^{\circ}-30^{\circ} \mathrm{S}$. lat. It reaches its maximum height here in the western Cordillera, between $22^{\circ} .27^{\circ} \mathrm{S}$., at over 21,000 feet, for the Llullaillaco, 21,800 feet, and the Nevada Ojo de las Losas, 21,800 feet, have no perpetual mantle of snow. In these regions the snow-line of the Ice Age lay remarkably bigh. Only little corries are found in the Bonete at 17,700 feet, and, in the eastern Cordillera, where the present snow-line is somewhat lower, we meet in Mount Chañi (20,300 feet high) lines of morainic deposit at 15,000 feet, pointing to the existence of a small glacier during the Ice Age, a phenomenon possible only with the snow-line over 16,500 feet. In the Sierra de Famatina corries are met with only at 17,000 feet, and this range is chiefly characterised by mountain-edges separating the steep slopes of the upper catchment-basins of mountain torrents, rather than by ridges running between the corries. However high the snow-line during the Ice Age was here, it was depressed in comparison with the snow-line of 
to-day by an amount which does not differ very much from that which we have found in the tropics and in the higher latitudes.

The fact that the snow-line in the arid region was specially high during the Ice Age, affords a new ground upon which opposition may be offered to the theory that the Ice Age was a period of excessive humidity, for had it been so the arid areas of the earth would have shrunk, and the snow-line in these areas would have descended to a specially great extent. As this is not the case, we may conclude that the Ice Age was rather a period of low temperature, and that this low temperature was universal throughout the world. For had the lowering of the temperature occurred on only one or the other hemisphere, as is demanded by Croll's theory, then the depression of the snow-line at the equator would not correspond as it does to the depression in temperate latitudes.

A general lowering of temperature, however, would bring about not only an advance in the snow-line, but at the same time a shifting of all climatic belts equatorwards. If the heat supply of the earth decreases, the atmospheric circulation will become less intense. The great areas of high pressure will become weaker, and the horse-latitudes must move towards the equator. And it is they that determine the position of the arid areas upon the land masses. Thus, everything points to the fact that the cataclimate of the great Ice Age was a period of reduced heat supply on the whole earth.

Geological research has proved that what we call the Ice Age, or the Great Ice Period, was not one continuous Ice Age, but consisted of several periods interchanging with non-glacial periods, during which the climate resembled that of the present day, but was somewhat warmer. There are good grounds for believing that during those interglacial periods the snow-line retreated farther than is to-day the case, and that from time to time the arid areas shifted farther polewards than we find them at present. All this indicates an interglacial period, which on account of the higher position of the snow-line, and the probable retreat of the arid areas into higher latitudes, we may designate as an anaclimatic period. The Great Ice Age would then appear to be an age of alternating cata- and anaclimatic periods, and an age moreover when there was considerable shifting of the climate zones, conditioned by variations in the heat supply of the earth.

The shifting of the climate belts, however, during the Ice Age has never gone so far that one belt has entirely usurped the position of another. Rather we meet everywhere with constant regions, where the climate has remained unaltered, where there has always been a snow, a humid, or an arid climate, and shifting regions, where snow and humid, humid and arid, and arid and humid, have alternated.

This conception does not agree with the view so widely accepted that the Ice Age was, outside the region of glaciation, a great Pluvial Period, for had this been the case the arid areas would entirely have vanished from the face of the earth. I have tried to show that this was not the case, although I am far from wishing to say that during the Ice Age these arid areas were not somewhat narrower than they now are. 
But the main fact remains unaltered that during the Ice Age the essentially tropic zone was smaller than at present. The arid areas of the northern and southern hemispheres approached one another, and in this shrinkage of the tropical humid zone the influence of an Ice Age in lower latitudes would be most clearly reflected; much more clearly than in a direct reduction of temperature : for even supposing this reduction by some few degrees did occur, it makes after all little difference whether the yearly average of a place at the equator is $80^{\circ} \mathrm{Fahr}$. or $75^{\circ} \mathrm{Fahr}$. Along with this shrinkage of the tropical zone during the Ice Age we have an extension of it during an interglacial period. We find for instance in the Sudan the laterite formation of the tropics traceable right up to the arid region.

The great arid areas could not easily vanish from the earth's surface, for their position is determined by the general atmospheric circulation. So long as the earth receives its warmth from the sun we must have horse-latitudes on sea, and these naturally condition desert areas on the land which lies on their eastern side. The position of the horse-latitudes may alter with any alteration in insolation, or in the position of the earth's axis. But disappear they cannot, and the desert areas which are thus linked to them can vanish only when there is no land surface in the said latitudes. As there must always be high pressure on land in these latitudes so there must always be a snow climate. According to the heat supply of the earth its height above sea-level will vary, attaining a specially high level in arid areas, and only from regions which rise above the snow-line can glaciers issue. Heavy glaciation thus presupposes a low snow-line and considerable altitude of land. Two factors must combine if an Ice Age is to exist. Every cataclimate need not be accompanied by extensive glaciation and shifting of the arid belts. Both these demand a definite land configuration which is not always present.

The shifting of the horse-latitudes can be caused as well by a general lowering of the heat supply of the earth as by a change in the obliquity of the earth's orbit. An increase of that obliquity will shift those belts towards the poles, a decrease towards the equator. But such a shifting will not be accompanied by a general movement of the snowlimit. When the horse-latitudes are shifted towards the poles by an increase of the obliquity of the earth's orbit, then the snow-line will be raised in the polar and the temperate regions, while it is lowered in the tropics, and a decrease in that obliquity will cause a rising of the snowline in the tropics, and a lowering of it in higher latitudes. Changes in the obliquity of the earth's orbit will never cause general anaclimatic or general cataclimatic periods, but will cause an anaclimatic time in one zone of the earth, and a cataclimatic in the other. General anaclimatic and cataclimatic periods have but one meaning; that is, changes in the heat supply of the earth. 